Юлія ШАПОВАЛОВА

\title{
ФЕНОМЕН ТВОРЧОСТІ БРАТІВ ДУРОВИХ: ПОГЛЯД СЬОГОДЕННЯ
}

У статті розглянуто життєвий шлях і методи творчості засновників циркової династії, дресирувальників тварин братів А. Л. Дурова та В. Л. Дурова. На тлі дебатів, які ведуться в сучасному суспільстві про можсливість заборони використання тварин у циирку, приклад творчості видатних дресирувальників може допомогти у вирішенні спірних питань.

Ключові слова: ичирк, дресура тварин, цииркове мистецтво.

В статье рассматриваются жизненный путь и методы творчества основателей цииковой династии дрессировщиков животных братьев А. Л. Дурова и В. Л. Дурова. На фоне дебатов, которые ведутся в современном обществе о возможности запрета использования животных в цирке, пример творчества выдаюшихся дрессировщиков может помочь в решении спорных вопросов.

Ключевые слова: ичирк, дрессировка животных, иирковое искусство.

The article considers the life path and methods of creativity of the brothers A. L. Durov and V.L.Durov are considered as the founders of the animal trainers' circus dynasty. Against the backdrop of the debate in modern society about the possibility of prohibiting the use of animals in the circus, the example of creativity of outstanding trainers can help in resolving disputes.

Key words: circus, animal training, circus art.

Діяльність у цирковій галузі не регулюється в Україні жодним спеціальним законом - навіть закон України «Про культуру» не містить визначення «циркове мистецтво», не говорячи про законодавче врегулювання складних взаємостосунків суб' єктів господарювання у цій сфері [5]. Зазначене не сприяє, зокрема, розв'язанню проблеми, що постала останніми роками в українському суспільстві з початком активного руху за цирк без тварин. Актуальність обраної теми статті обумовлена сучасними дебатами про подальшу долю тварин в українському цирку. Можливо, цирк без тварин - це гарна ідея, але, як часто буває, не до кінця продумана. Як прибічники, так і супротивники мають щодо цієї традиції свої докази.

Прибічники використання тварин у цирку стверджують: якщо в цирку заборонять використовувати тварин, їх просто знищать, бо їх ніде буде подіти. Жоден зоопарк не візьме собі тварин із цирку, бо такі тварини не виживуть в умовах зоопарку. Крім того, циркові тварини беруться не 3 природного середовища, а з декількох так званих «поколінь неволі». Дресирувальники стверджують, що циркові тварини живуть утричі довше, ніж в умовах дикої природи, та вдвічі довше, ніж у зоопарку.
Громадські зоозахисники стверджують, що дресирувальники жорстоко поводяться з тваринами, б'ють звірів, змушують їх виконувати рухи, невластиві тваринам у дикій природі, а умови, в яких містяться чотирилапі, залишають бажати кращого.

Іноді, для того щоб вирішити якесь спірне питання, варто звернутися до історії, до постатей людей, творчість яких залишила яскравий слід, стала підгрунтям для праці багатьох послідовників і методи творчості яких не втратили своєї актуальності в наш час.

Мета иісї статті - дослідити феномен творчості видатних дресирувальників братів Дурових, які вперше поставили дресуру диких тварин на наукову основу, застосували гуманні методи, засновані на умовних рефлексах.

Звичайно, коли йдеться про цирк, про знаменитих дресирувальників тварин, на думку спадає прізвище Дуров. Але це прізвище належить двом братам: Анатолію Леонідовичу (1864-1915) та Володимиру Леонідовичу (1863-1934). Кожен 3 них був відомим дресирувальником тварин. Брати зробили великий внесок у подальший розвиток циркового мистецтва. Сформулювали і вдоскона- 
лили нові, гуманні методи дресирування тварин, які тепер є основою сучасного українського та світового цирку.

Народилися брати у Москві. За походженням були дворянами. Слід зазначити, що у той час аристократія ставилася до цирку з огидою. Вважалося, що бути актором цирку - забава для простолюдинів. Батьки у братів померли рано і опікуватися ними почав хрещений батько Н. З. Захаров - відомий на той час адвокат. Він був солідною людиною, до хрещеників ставився доброзичливо. Стосунки були добрі, хлопці були ситі, одягнені, їм давали кишенькові гроші, але справжнього сімейного тепла вони не відчували. Окрім того, у родині виникало багато суперечок через вибір братів піти в циркові актори.

Н. 3. Захаров прилаштував хлопців у тодішній Перший московський кадетський корпус, де вони навчалися разом із відомим письменником О. Купріним. Він згадував, що Анатолій Дуров дійшов лише до 3-го класу. Мав конфлікти з начальством, бо під партою в нього часто жили різні тварини: жаби, пацюки і ящірки. Врешті-решт братів відрахували.

Обидва хлопці були дуже несхожі між собою, водночас їх поєднувала любов до цирку. Треба зазначити, що творчий шлях братів розійшовся з самого початку. Вони жодного разу не виступали разом та навіть ніколи в одному місті.

Анатолій Дуров більше тяжів до акробатики, гімнастики та клоунади. Він намагався побувати на всіх гуляннях, балаганах, виставах, де виступали циркові артисти та познайомитись 3 ними. Він запросив вершника 3 цирку Гінне Анджело Бріаторі стати його вчителем, потім його змінив артист одного з балаганів Отто Клейст $[1,9]$. Під час тренувань А. Дуров просив вчителя шмагати його батогом за помилки. Постійні фізичні вправи зіграли позитивну роль і підготували його до досить нелегкого шляху циркового артиста.

У 1880 р. Анатолій Дуров пішов з дому і почав виступати в балагані В.А. Вайнштока. Умови для акторів були нелегкими. Балаган постійно гастролював, переїжджаючи з місця на місце. Вайншток для всіх акторів знімав одну кімнату без меблів. Спати доводилось на підлозі, i через холод дехто i не роздягався. Замість подушок актори клали поліно, загорнуте в ганчір'я. Виступи були не дуже вдалими - трупа за чарку горілки давала виставу в шинках. Дуров, на відміну від інших, не пив. Його пригощали бутербродами та пиріжками. Багато хто 3 акторів не мав паспорта. Цей період був дуже важким для А. Дурова, але вже тоді його виступи відзначалися їдкою сатирою на чиновників і можновладців, що викликало симпатію публіки.
Після повернення до Москви, незважаючи на умовляння рідних кинути цирк, А. Дуров влаштувався до трупи С. М. Рінальдо. Пізніше він почав виступати з акробатами і жонглерами братами Робінзон-Ніколет. 3 ними почав мандрувати. Побував у Харкові, Одесі, Ризі. Після цього його шляхи з братами розійшлись, і він поїхав у місто Воронеж, у якому вперше спробував жанр клоунади. У цьому місті, в майбутньому, буде відкритий музей А. Дурова.

На початку кар'єри А. Дуров шукав сценічний образ, який би вирізняв його з-поміж інших клоунів. Спочатку він виступав з набіленим обличчям, яскраво-червоною помадою на губах. Одягнений був у типове клоунське вбрання: яскраві широченні штани, здоровенний білий бант на грудях [9].

Від самого початку своєї діяльності А. Дуров прагнув пропонувати глядачам щось незвичайне, чудове. У Воронежі вперше починає займатися дресируванням. У нього були баран, півень та порося, 3 якими виступав і ставав дедалі відомішим і популярнішим. Через свою популярність А. Дуров нажив ворогів, які всіляко перешкоджали його виставам. У книжках, присвячених діяльності А. Дурова, $є$ багато прикладів жорстокого ставлення «колег» як до самого артиста, так і до його звірів [9].

У 1884 році актор повертається до Москви. На той час тут виступала відома циркова трупа, якою керував Шуман. Як було у звичаї того часу, у цирку Шумана виступали лише іноземці. Все ж незабаром Анатолій Дуров став там прем'єром. Афіші, навіть навмисно вказували, що виступатиме людина російського походження.

У той час клоуни шили костюми з ситцю. Можливостей пошити на замовлення костюм у А. Дурова не було, і він, позичивши у хрещеного батька дорогу портьєру, зробив собі оригінальний костюм, якого не було в жодного клоуна. На ноги вдягнув панчохи, до костюма додав коротку накидку і лаковані туфлі. Тоді ж відмовився від ковпака і навіть перестав білити обличчя. Так на прем'єрі у Шумана з'явився новий шикарний і чарівний клоун. Це був артист, до якого з того моменту прийшла слава.

O. I. Купрін написав: «Цей найвидатніший російський цирковий артист уперше показав, що клоун - не блазень, а артист і сатирик, що він гідний свого власного пам'ятника, нехай за сучасних умов і не в бронзі, а хоча б у вдячних серцях (переклад наш - Ю. Ш.)» [6].

Зазвичай у ті часи прізвища артистів не оголошувалися, однак перед виходом А. Дурова всі учасники вистави і уніформісти вишиковувалися у дві шеренги і ведучий урочисто сповіщав: «Анатолій 
Дуров!», після чого актор з'являвся на арені. Він обходив арену, піднісши вгору руки, і вітав глядачів. Публіка шаленіла та і нагороджувала аплодисментами свого улюбленого артиста.

Дуров не був політичним діячем і не міг вирішувати глобальні питання. Але міг сміливо, навіть зухвало, говорити про владу. Виступав проти усіх форм мракобісся, вульгарності. Він не боявся критикувати можновладців, вказував на бюрократизм, корупцію. У свої книжці «В жизни и на арене» епіграфом він поставив такі рядки:

«У всякого свое оружие, друзья!

Есть жало у пчелы, у воина копье,

Владею силой так же я:

Насмешка едкая - оружие мое» [3].

Про себе Анатолій Дуров казав, що він «король шутов, но не шут королей». Своїми виступами, котрі мали великий успіх у пересічних людей та викликали озлобленість можновладців, він щоразу підтверджував це. Виступав актор і за кордоном. 3 1890-го по 1891 роки А. Дуров гастролював у цирках Іспанії, Франції, Італії, Австрії. Всюди його вистави мали великий успіх. У 1895-му в Дюссельдорфі була надрукована «Загальна енциклопедія циркового мистецтва». Сдиним російським артистом, якому була присвячена окрема стаття, був Анатолій Дуров.

Основу його номерів становили дресировані тварини. Він ніколи не досягав таких висот у дресуpi, як його брат Володимир, який працював з багатьма видами диких тварин, у тому числі екзотичних. Але успішно використовував домашніх тварин, особливо полюбляв виступати зі свиньми, яких вважав розумними.

Із дресированими тваринами А. Дуров створював сатиричні номери, у яких в алегоричній формі висміював дурість, жадібність, зарозумілість можновладців. У творах, присвячених його творчості, $€$ багато цікавих прикладів того, наскільки він ядуче й оригінально ставив на місце пихатих хамів. Загальновідомо, як він висміяв у 1891 році одеського градоначальника П. А. Зеленого, грубість і дурість якого викликала ненависть до нього у населення Одеси. Актора попередили, що градоначальник має прийти на виставу, і перед початком свого виступу А. Дуров пофарбував свиню у зелений колір. У такому вигляді він і вивів ії на арену. Номер мав шалений успіх у публіки, але за це актора вислали з Одеси.

Звісно, Анатолій Дуров був більше клоуном-сатириком аніж дресирувальником. Тварин він використовував як допомогу для номеру, щоб краще донести його ідею до глядачів. Все ж йому постійно доводилося займатися дресурою, і в 1887 році він вже мав для виступів козла, баранів, лисиць i, звісно, його улюблених свинок. У 1890 році у нього з'явилися коти. Ще задовго до появи клоуна Куклачова номери ставились за участю котів. У А. Дурова кішки підіймали прапор, стріляли з револьвера та гарматок. Їх було чотири. Песики-учасники «співали» дуетом, свинки вальсували, а півень починав кукурікати лише після команди дресирувальника. Усе це потребувало терпіння у дресируванні, розуміння поведінки тварин і любові до них. Потім він вигадав ще один оригінальний номер. На арені була зроблена мініатюрна залізна дорога, пацюки були машиністами, пасажирами та кондукторами. Цей номер завжди викликав захват у глядачів, особливо у дитячої аудиторії.

У 1896 р. А. Дуров почав демонструвати номер «Пригоди в місті Свинську», де були задіяні до 70-ти свиней. Були збудовані декорації, котрі представляли містечко у зменшеному вигляді. В центрі височіла пожежна каланча. Вистава демонструвала, як пожежники рятують будинок, що горить. Виконавцями цієї вистави - i пожежниками, і погорільцями були маленькі поросята. Постановка такого номера вимагала майстерності у дресурі. Навіть сьогодні це було б захоплюючим видовищем. Сучасному циркові такого видовища вочевидь не вистачає.

Коли А. Дуров вже став знаменитим актором, то займав своїми номерами ціле відділення, зазвичай трете, і в інших циркових діях більше участі не брав. Популярність його була настільки великою, що акторові влаштовували окремі бенефіси.

А. Дуров багато думав про сутність клоунади. Що вона може дати? Що дає? Яке ії призначення? У 1913 році в Москві Анатолій Дуров провів лекцію у великій аудиторії Політехнічного музею. Лекція називалася «О смехе и о жрецах смеха». Готуючись до цієї лекції, він цитував французького філософа Анрі Бергсона, який написав книжку «Сміх у житті і на сцені». Ця книжка була тоді на піку популярності. Але багато нових ідей і думок належало самому А. Дурову. Лекцію він поділив на дві частини. У першій частині розглядалася теорія про комічність, а у другій — теорія клоунади [2].

До клоунів він ставився як до митців. Але лише до тих, хто міг аналізувати події, що відбувалися у суспільстві та дати їм правильну оцінку. Лише тоді, на його думку, людина може назвати себе справжнім клоуном. Проте найпершою важливою умовою $є$ талант. Постійна праця над собою і талант. Лише за цих умов клоун може створити справжній художній твір. У клоунаді нічого не може бути зайвого. «Клоун може бути як Сальвіні, різниця лише у напрямку їх талантів»,- стверджував А. Дуров у своїй книжці [3]. 
На принципово інший рівень вивів дресуру тварин брат Анатолія - Володимир Дуров. Він вивчав праці I. М. Сєченова, І. П. Павлова, залучав до своєї роботи психологів і психіатрів. Саме у московському домі Володимира Дурова відкрився театр звірів «Куточок Дурова».

3 дитинства він мав пристрасть до тварин і вирішив пов'язати 3 ними свою долю, ставши дресирувальником. У 1881 році В. Дуров улаштувався працювати у цирк-звіринець Гуго Вінклера. Тут він ставив номери із собакою, козлом та морськими свинками. Чим більше працював із тваринами тим більше зрозумів, що йому не вистачає знань. Повернувся з гастролей додому і вступив на навчання до училища, котрим керував Д. І. Тихомиров. Там готували вчителів для земських шкіл. Багато учнів цього училища перебували під впливом ідей Л. М. Толстого і займалися самовдосконаленням. Саме в училищі Володимир Дуров почав відвідувати лекції фізіолога I. М. Сєченова.

Майбутній актор мав аналітичний розум і потяг до навчання та вивчення навколишнього світу. Вивчаючи тварин, В. Дуров вперше висловив думку про умовні рефлекси. Тодішні циркові методи дресирування були доволі жорстокі. Спостерігаючи за собаками вуличних артистів, він обурювався тим, що тварини мали нещасний вигляд, а дресирувальника вочевидь боялися. Зовсім іншими засобами дресури почав користуватися В. Дуров. Пізніше, у 1882 році він видав книжку: «Записки дуровской свиньи», у якій пояснював основи дресури тварин. На його думку, метод ласощів як заохочення - $\epsilon$ найефективнішим у дресируванні. «Основними умовами мого методу є бадьорий, творчий настрій тварин. Нi біль, ні голод, ні перевтома недопустимі (переклад наш - Ю. Ш.)». Звичайно, дресура - це нелегка праця, однак з часом актор домагався бажаного результату. Скажімо, із свинею, котру він вчив вальсувати. Він змазував хліб салом і водив біля носика свинки, а потім пригощав. Це потребувало часу і терпіння. 3 часом, коли він тільки повертав руку, свиня починала сама робити оберт. Дресирування Дурова спиралося на умовні рефлекси. Ніколи він не знущався з тварин, а покарань намагався уникати. До того як почати дресирувати певну тварину він вивчав про неї різну інформацію: як живе тварина в природних умовах? як це можна використати?

Дуров любив тварин і ніколи не йшов проти їх природної натури. Мав багато диких тварин, які, як вважалося, не піддаються дресурі. Але, спостерігаючи їх поведінку та звички, В. Дуров знаходив засоби для успішного дресирування. Наприклад, завдяки притаманній йому допитливості він дізнав- ся, що пелікани, коли шукають їжу під камінням, зрушують його дзьобом. Так народилася ідея про номер, де пелікан умів «читати». Пелікан перегортав сторінки книжки ніби читав іiі, але книжки незвичайної. Її зробили з фанери і під «сторінки» підкладали маленьких, непомітних рибок, щоби пелікан шукав їх. Публіці здавалося, що пелікан насправді читав. Звісно, номер мав шалений успіх.

3 цим пеліканом трапилася кумедна і водночас сумна історія. Володимир Дуров поїхав до Астрахані на гастролі. Один із робітників цирку, відкрив шапіто для провітрювання, i, звісно, пелікан полетів собі. Дуров був у розпачі. Про це почув капітан одного $з$ пароплавів і привіз Дурову нового пелікана.

Головним принципом праці з тваринами у В. Дурова був принцип трьох «Л»: любов, ласка, ласощі. Він неодноразово наголошував: «В основу моей дрессировки заложена проповедь любви, отрицающая всякое насилие. Мои ученики каждый раз за выполнение задания в виде поощрения получают лакомство, что заставляет их охотно выполнять задание» [4].

У 1887 році Володимир показував уже дресированих вовка та собаку, останній зображав «математика». Номер був поданий так: на арені скрізь були розкладені цифри на картках — від одиниці до дев'ятки. Публіці пропонували задати задачу на множення, ділення, додавання або віднімання. Собака підіймав потрібну картку. Задачу вирішував насправді дресирувальник і подавав відповідні знаки собаці. В. Дуров пізніше говорив, що цирк може не лише розважати, а й повчати.

У 1907 р. був показаний славнозвісний номер про залізницю. Рейки прокладалися впоперек арени, по них рухався локомотив та три вагони: два пасажирських і багажний. Дуров жартами коментував те, що відбувалося на арені. Контролера зображав козел, машиністом була мавпа, а друга - стрілочником. За пасажирів правили морські свинки, гуси виконували роль носіїв, качка - станційного наглядача; заєць їхав, сидячи на буфері, чапля ходила по шпалах за поїздом.

Володимир Дуров написав про тварин книжку «Дрессировка животных». У передмові до неї відомі вчені зі зоопсихології, такі, як професор Г. А. Кожевников і А. В. Леонтович писали: «Дуров намагається врахувати внутрішній світ тварини, внутрішні мотиви ii дій, з любов'ю звертається до тварини, як до людиноподібної, але зі своєрідною психікою, використовуючи при цьому навіть методи гіпнозу». Науковими дослідами В. Дурова цікавились багато вчених, в тому числі академік В. М. Бехтєрєв [9]. 
У 1911 р. В. Дуров мав уже слона, морських левів, верблюдів, мавп, пеліканів, свиней, собак та інших тварин - всього понад 50 видів. В усьому світі ніхто не мав на той час стільки дресированих тварин. Він застосовував свою методику зоопсихології та дресирування без болю, провадив до кінця свого життя наукову роботу.

Брати Дурови заснували сімейну династію дресирувальників, яка успішно застосовує їх методи дресирування і у наші часи. Традиції Дурових продовжили такі видатні дресирувальники як І. Бугрімова, династія Запашних, Ю. Куклачов, М. Назарова, подружжя Володимир і Людмила Шевченки та інші.

Ось як коментує сучасний диспут про заборону чи подальше використання тварин у цирку знаменитий дресирувальник Едгар Запашний: «Цирк дю Солей на своє перше шоу планував зробити номер із слонами. Вони навіть ворота для виходу на арену спеціально зробили високими. Але їм не вистачило грошей на купівлю тварин. Пізніше із цісї ситуації вони зробили грамотну рекламу — мовляв, у нас перший цирк без тварин... У одного із співвласників цього цирку є власне кінне шоу в Канаді. До речі, далеко не всюди Цирк дю Солей користується великим успіхом. Саме через відсутність тварин. Хижаки у цирку завдяки якісному ветеринарному обслуговуванню, правильній годівлі та утриманню живуть удвічі довше, ніж у природних умовах. Хоча, безперечно, потрібно враховувати й критику захисників тварин. Вважаю, що потрібно ввести ліцензування професії дресирувальника аби поставити заслін усім цим шапіто, які роз'їжджають безконтрольно, де звірів мучать і вони звідти збігають і можуть напасти на людей» [8]. А Аскольд Запашний додає: «Якщо починати спочатку, то люди самі вижили тварин із їхнього природного середовища, побудувавши міста» [8].

Про гуманне поводження із тваринами йдеться й у ст. 14 проекту Закону «Про цирки та циркову діяльність в Україні», який, слід сподіватися, найближчим часом буде прийнятий: «Під час підготовки та показу циркових програм не допускається створення загроз життю і здоров'ю глядачів, жорстоке поводження з тваринами при транспортуванні, утриманні і виступах» [7].

Зрозуміло, що життя рухається вперед, а разом з ним розвивається і мистецтво - усі його види, в тому числі і цирк; шукають нові форми, фарби, новий зміст. Але при цьому повинні зберігатися найліпші традиції, потрібно розвивати їх, відшуковуючи дедалі нові засоби виразності. Відбувається еволюція циркових вистав, які стають більш театралізованими, поліпшується їх технічне забезпе- чення. Вдосконалюється майстерність циркових акторів, але при цьому бажано, щоби чотирилапі актори зберегли своє місце на арені як повноправні учасники циркової вистави.

Слід мати на увазі, що український цирк $\epsilon$ яскравим представником так званого традиційного цирку, що налічує понад 250 років, де номери 3 дресированими тваринами посідають чільне місце. Відмова від тварин означатиме, що традиційна мистецька складова українського цирку має бути змінена. Чи збереже національний цирк після такої зміни свою неповторність, чи вона буде втрачена назавжди? На це запитання слід дати відповідь усім причетним перед прийняттям доленосних рішень.

На нашу думку, вирішити проблему, пов'язану 3 тваринами у цирку, допомогли би такі загальнодержавні заходи:

заборона використання у цирках червонокнижних тварин (законодавче затвердження відповідного переліку);

жорсткий контроль за належними умовами утримання тварин у цирках як з боку уповноважених органів, так і громадських організацій;

посилення покарання за жорстоке поводження з тваринами у цирку;

введення у програмах спеціалізованих навчальних закладів сертифікованих курсів дресирувальників і недопущення до роботи з тваринами осіб без таких сертифікатів.

\section{Джерела та література}

1. Бардиан Ф. Г. Советский цирк на пяти континентах. Москва: Искусство, 1977. 206 с.

2. Газетные старости. [Електронний ресурс]. Режим доступу: http://starosti. ru/article. php?id=35397

3. Дуров А. Л. В жизни и на арене. Москва: Искусство, 1984. $198 \mathrm{c}$.

4. Дуров В. Л. Мои звери. Москва-Берлин: Директ-Медиа, 2016. 104 c.

5. Закон України «Про культуру». [Електронний ресурс]. Режим доступу: http://zakon5. rada. gov. ua/laws/show/277817\#Find

6. Куприн А. И. О Анатолии Дурове. [Електронний ресурс]. Режим доступу: http://liv. piramidin. com/belas/Kuprin/o_ durowe. htm

7. Проект закону «Про цирк та циркову діяльність». [Електронний ресурс]. Режим доступу: http://w1. c1. rada. gov. ua/pls/zweb2/webproc4_1?pf3511=48432

8. Худенко К. Аскольд Запашный против рижских защитников животных. [Електронний ресурс]. Режим доступу: https://inosmi. ru/sngbaltia/20150515/228038184. html

9. Энциклопедия «Мир цирка». Т. 1. [Електронний ресурс]. Режим доступу: http://www. peoples. ru/art/circus/clown/ durov/

\section{References}

1. Bardian F. G. (1977). Soviet circus on five continents. Moskva: Isskustvo, 206 [in Russian]. 
2. Newspaper old age. http://starosti. ru/article. php?id= 35397.

3. Durov A. L. (1984). In life and in the arena. Moskva: Isskustvo, 198 [in Russian].

4. Duruv V. L. (2016). My animals. Moskva-Berlin: Direkt-Media, 104 [in Russian].

5. The Law of Ukraine «About Culture». http://zakon5. rada. gov. ua/laws/show/2778-17\#Find
6. Kuprin A. I. About Anatoly Durov. http://liv. piramidin. com/ belas/Kuprin/o_durowe. htm

7. Proekt zakonu «About the circus and circus activity». http://w1. c1. rada. gov. ua/pls/zweb2/webproc4_1?pf3511=48432

8. Hudenko K. Askold Zapashny against the Riga animal advocates. https://inosmi. ru/sngbaltia/20150515/228038184. html

9. Encyclopedia "The World of Circus". V.1. http://www. peoples. $\mathrm{ru} / \mathrm{art} / \mathrm{circus} /$ clown/durov/ 